\title{
A comparison of the absorption and retention by rabbits of strontium-90 incorporated into plant material and of added strontium chloride in the diet
}

\author{
BY T. E. F. CARR AND JULIE WALL \\ Medical Research Council Radiobiological Research Unit, Harwell, Didcot, Berks.
}

(Received 8 fune 1960-Revised 31 October 1960)

A large part of the strontium-9o from fallout that reaches man is from fallout on vegetation, and any process affecting its absorption by animals affects its transfer to man. The ${ }^{90} \mathrm{Sr}$ content of vegetation comes from two sources, that in the soil from previous fallout which is incorporated through the roots into the plant tissue, and that from current fallout producing a surface contamination of the plant (Russell, I959). This surface contamination may in turn also be incorporated into the plant tissue (Middleton, 1958; Morgan, 1959).

It is known that several organic substances present in plants, e.g. phytic acid, can affect calcium and strontium absorption from the gut of animals (Nicolaysen, ErgLarsen \& Malm, I953; Irving, 1957). It was not obvious whether such an effect would be found equally for $\mathrm{Sr}$ incorporated in grass tissues and strontium chloride added to the same diet. Conflicting evidence on this problem has been produced by other workers (Gross, Taylor, Lee \& Watson, 1953; Horstman, Selders, Nicholson, Hungate \& Bustad, 1957). Sr in world-wide fallout has been shown to be as readily absorbed from the gut of animals as a solution of its chloride when added to the diet (Carr, Harrison \& Sutton, 1959) and so is similar in availability to surface contamination of grass. Samples of grass hay containing incorporated ${ }^{90} \mathrm{Sr}$ were available from the Agricultural Research Council Radiobiological Laboratory at Compton from experiments on the uptake of ${ }^{90} \mathrm{Sr}$ from the soil by grass. Perennial rye-grass was grown on a soil profile taken from various localities and contained in a concrete cylinder, the ${ }^{90} \mathrm{Sr}$ being added at or just below the surface. Various cuts of the grass were made during the growing season and dried for storage and assay. The samples consequently contained rather more of the young leaves than in normal hay cuts from the field and were similar to the intake of a grazing animal.

An experiment with bulked samples of this dried grass from several cylinders was carried out to check the relative absorption from the diet, simultaneously in the same animal, of this incorporated ${ }^{90} \mathrm{Sr}$ and added strontium chloride.

\section{EXPERIMENTAL}

Animals and diet. The levels of ${ }^{90} \mathrm{Sr}$ in the grass-hay samples were sufficiently high to permit short feeding experiments on small animals. Since grass normally comprises a large part of the diet of rabbits, Dutch male rabbits, 6 months old and 
weighing about $\mathrm{I} \cdot 4 \mathrm{~kg}$, were used in standard laboratory metabolism cages. The grass containing the incorporated ${ }^{90} \mathrm{Sr}$ was dried at $80^{\circ}$ and powdered, and 70 parts by weight of the powder were thoroughly mixed with 20 parts of white flour, 5 parts of dried egg white and 5 parts of sucrose. This mixture was moistened, at which time a trace of ${ }^{85} \mathrm{SrCl}_{2}$ was added. ${ }^{85} \mathrm{Sr}$ is a $\gamma$-ray-emitting nuclide which can be readily assayed in the presence of ${ }^{90} \mathrm{Sr}$. The resultant paste was extruded under pressure and dried to form pellets acceptable to the rabbits.

Samples and assay. Two rabbits were fed during I day and killed I day later, by which time the bulk of the unabsorbed Sr would be in the faeces. Two others were fed continuously for $2 \mathrm{I}$ days and killed I day after the last feed. Faeces and urine were collected daily for radioactive assay. After the rabbits were killed, the gut with its contents and the liver and kidneys were removed for assay and the skeleton was roughly dissected from the residual carcass. All samples were ashed at $600^{\circ}$, the resultant ash being dissolved in $6 \mathrm{~N}$-nitric acid.

The radioactive assay of these solutions for the $\beta$-radiation of the ${ }^{90} \mathrm{Sr}+{ }^{90} \mathrm{Y}$ was made in an $\mathrm{M} 6 \mathrm{H}$ liquid counter (2oth Century Electronics, New Addington, Croydon, Surrey) and for the $\gamma$-radiation of the ${ }^{85} \mathrm{Sr}$ in a well-type sodium-iodide scintillating detector with a $2 \mathrm{~mm}$ thick lead screen round the sample. The interference of the $\beta$-radiation in the scintillating crystal had previously been measured and found to be $I \cdot I \%$ and the interference of the $\gamma$-radiation in the $\mathrm{M} 6 \mathrm{H}$ counter found to be $\mathrm{I} \cdot 2 \%$. These corrections were applied to the respective count rates after each sample had been counted in both counters and all count rates were corrected for radioactive decay and for the resolving time in the separate counters.

\section{RESULTS}

The results for the short feeding experiment are given in Table $\mathbf{I}$ and for the longer feeding period in Table 2. In both tables the estimated dose is given together with the recovered amount of each isotope from the total assay on each rabbit. The estimated dose was based on a small sample of the food to be eaten so that the recovered dose was considered the better estimate of the amount administered, and hence all values for the samples are expressed as percentages of the recovered dose.

The figure given for retention is the total percentage found in all tissues excluding the gut and contents. The absorption is expressed as the percentage retained together with that excreted in the urine.but excluding any endogenous excretion in the faeces which could not be estimated in this experiment.

In the short feeding experiment both rabbits absorbed about $14 \%$ of the dose and retained about $4.5 \%$ in the tissues $24 \mathrm{~h}$ after the administration of both nuclides. In the longer experiment, lasting $2 \mathrm{I}$ days, about $25 \%$ of the dose was absorbed by both rabbits. The retention by rabbit no. 3 , however, was $8 \%$, almost twice that of rabbit no. 4 whose retention $(4.5 \%)$ was similar to that of the two rabbits in the first experiment. This higher retention was mainly skeletal and was reflected in the smaller percentage excreted in the urine. There was no significant difference in the behaviour of the two forms of Sr. 
Table I. Distribution, retention and absorption of strontium in two rabbits after $24 h$ on a diet with incorporated ${ }^{90} \mathrm{Sr}$ and added ${ }^{85} \mathrm{SrCl}_{2}$, expressed as a percentage of the recovered dose (see p. I66)

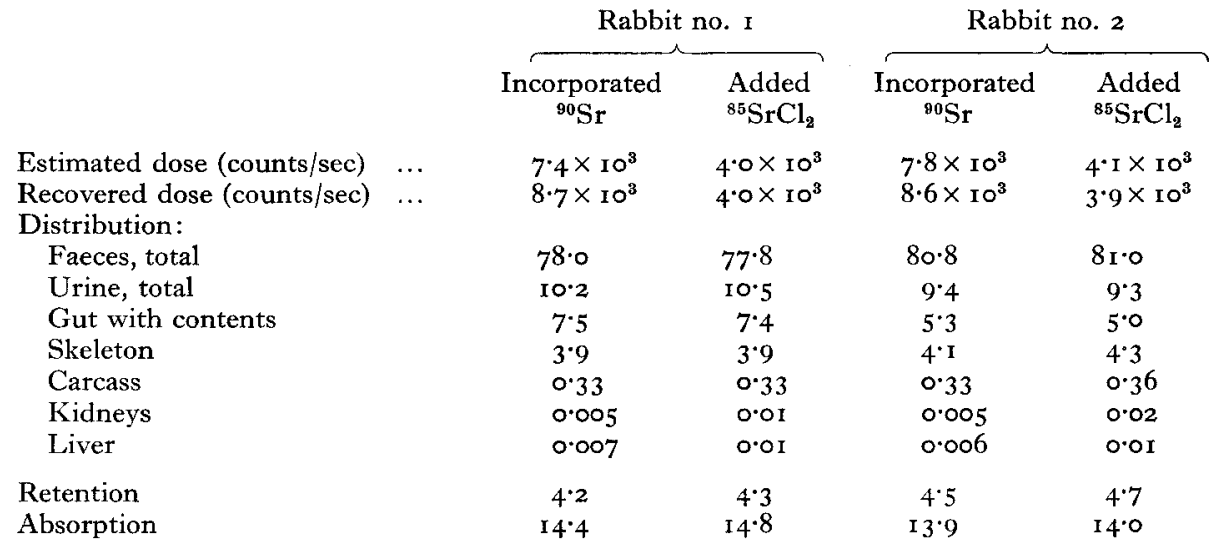

Table 2. Distribution, retention and absorption of strontium in two rabbits after $2 \mathrm{I}$ days on a diet with incorporated ${ }^{90} \mathrm{Sr}$ and added ${ }^{85} \mathrm{SrCl}_{2}$, expressed as a percentage of the recovered dose (see p. I66)

\begin{tabular}{|c|c|c|c|c|c|}
\hline & & \multicolumn{2}{|c|}{ Rabbit no. 3} & \multicolumn{2}{|c|}{ Rabbit no. 4} \\
\hline & & $\begin{array}{l}\text { Incorporated } \\
{ }^{90} \mathrm{Sr}\end{array}$ & $\begin{array}{l}\text { Added } \\
{ }^{85} \mathrm{SrCl}_{2}\end{array}$ & $\begin{array}{c}\text { Incorporated } \\
{ }^{90} \mathrm{Sr}\end{array}$ & $\begin{array}{l}\text { Added } \\
{ }^{85} \mathrm{SrCl}_{2}\end{array}$ \\
\hline Estimated dose (counts/sec) & $\ldots$ & $4.3 \times 10^{4}$ & $3.6 \times 10^{4}$ & $4.9 \times 10^{4}$ & $4.1 \times 10^{4}$ \\
\hline Recovered dose (counts/sec) & $\ldots$ & $3.7 \times 10^{4}$ & $3.3 \times 10^{4}$ & $4.4 \times 10^{4}$ & $3.9 \times 10^{4}$ \\
\hline \multicolumn{6}{|l|}{ Distribution: } \\
\hline Faeces, total & & $75 \cdot 3$ & $75^{\circ} 5$ & $73 \cdot 8$ & $73 \cdot 8$ \\
\hline Urine, total & & 16.2 & $16 \cdot 1$ & $2 I \cdot I$ & $20 \cdot 1$ \\
\hline Gut with contents & & $0 \cdot 3^{8}$ & 0.32 & 0.43 & 0.44 \\
\hline Skeleton & & $7 \cdot 9$ & $7 \cdot 8$ & $4 \cdot 6$ & $4 \cdot 7$ \\
\hline Carcass & & $0 \cdot 18$ & 0.15 & 0.06 & 0.11 \\
\hline Kidneys & & 0.001 & 0.001 & 0.001 & 0.003 \\
\hline Liver & & 0.001 & 0.001 & 0.002 & 0.006 \\
\hline Retention & & $8 \cdot 1$ & $8 \cdot 0$ & $4 \cdot 7$ & $4 \cdot 8$ \\
\hline Absorption & & $24 \cdot 3$ & $24 \cdot I$ & $25 \cdot 8$ & $24^{\circ} 9$ \\
\hline
\end{tabular}

\section{DISCUSSION}

Although there were slight variations between the percentages of the two $\mathrm{Sr}$ isotopes found in the various fractions, it may be concluded that there was no difference in their absorption or retention. The small differences between the different rabbits were well within the limits of error of the experimental technique, especially with the longer period of feeding when the count rates were lower and many more assays were involved than with the I-day feeding.

This result agrees with that of Horstman et al. (1957), who reported no difference in the ${ }^{90} \mathrm{Sr}$ levels in milk from ewes given ${ }^{90} \mathrm{Sr}$ for short periods, either as nitrate or incorporated into barley hay. On the other hand, Gross et al. (1953) gave results 
obtained by feeding rats on barley or lettuce grown on soils contaminated with ${ }^{90} \mathrm{Sr}$ and compared them with results for the ${ }^{90} \mathrm{Sr}$ uptake in rats given uncontaminated barley or lettuce with added ${ }^{90} \mathrm{Sr}$ solution. There appeared to be a smaller uptake of ${ }^{90} \mathrm{Sr}$ when plants were grown on contaminated soil than when the ${ }^{90} \mathrm{Sr}$ was added to the previously uncontaminated food. Gross et al. were making comparisons between groups of rats given radioactive $\mathrm{Sr}$ from one or the other source and did not make comparisons on the same animal.

It may be concluded, therefore, that for rabbits the relative 'availability' of Sr incorporated into grass is the same as for strontium-chloride solution in an identical diet. Hence it appears that these two forms of Sr enter a common gut pool and are interchangeable even though the overall uptake of this element may be reduced or increased by changes in the amounts in the diet of phytates or other organic materials found in plants.

\section{SUMMARY}

I. Since it is known that organic substances in plants can affect the absorption by animals of calcium and strontium from the gut, a comparison has been made of the absorption and retention of ${ }^{90} \mathrm{Sr}$ incorporated into plant tissues and of ${ }^{85} \mathrm{SrCl}_{2}$ added to the diet of rabbits. The diet consisted mainly of dried grass containing the incorporated ${ }^{90} \mathrm{Sr}$.

2. Four rabbits were given this diet; two were given it for I day and were killed I day later, and two were given it for 21 days and were killed on the 22nd day. The two nuclides were then determined in samples of urine, faeces and tissues.

3. No difference was found in the behaviour of these two forms of $\mathrm{Sr}$ after their simultaneous administration to the rabbit.

The authors thank Dr L. J. Middleton of the Agricultural Research Council Radiobiological Laboratory for supplying the grass containing ${ }^{90} \mathrm{Sr}$.

\section{REFERENCES}

Carr, T. E. F., Harrison, G. E. \& Sutton, A. (1959). The Distribution of Radioactivity in Rabbits Following Ingestion of Fission Products Collected from Atomic Weapon Clouds. Atomic Weapons Research Establishment, Aldermaston. Rep T $57 / 58$, Part 5.

Gross, W. J., Taylor, J. F., Lee, J. A. \& Watson, J. C. (1953). The Availability of Radio-strontium to Mammals by Way of the Food Chain. (UCLA-259-Health and Biology, Los Angeles, University of California) (mimeo.).

Horstman, V. G., Selders, A. A., Nicholson, W. L., Hungate, F. P. \& Bustad, L. K. (1957). Turnover of Inorganic versus Plant Incorporated $\mathrm{Sr}^{90}$ to Sheep Milk. AEC Research and Development Report HW-47500, p. 79. (General Electric, Hanford Laboratories, Biology Research Annual Report, 1956). Washington, D.C.: U.S. Atomic Energy Commission.

Irving, J. T. (1957). Calcium Metabolism. London: Methuen and Co. Ltd.

Middleton, L. J. (1958). Nature, Lond., r8r, I 300.

Morgan, A. (1959). F. nucl. Energy, Part A. Reactor Science, II, 8.

Nicolaysen, R., Erg-Larsen, N. \& Malm, O. J. (1953). Physiol. Rev. 33, 424.

Russell, R. S. (1959). Rep. Agricultural Research Council, Radiobiological Laboratory no. 1. London: H.M. Stationery Office. 